Personalidade Acadêmica Homenageada:

Augustus B. Cochran III (Agnes Scott College)

\title{
A OBRIGATORIEDADE DA ROTULAGEM DE ALIMENTOS TRANSGÊNICOS
}

\section{THE OBLIGATION OF TRANSGENIC FOOD LABELING}

\begin{abstract}
VALMIR CÉSAR POZZETTI
Doutor em Biodireito pela Université de Limoges/França. Professor Adjunto do Programa de Mestrado em Direito Ambiental da UEA - Universidade do Estado do Amazonas e Prof. Adjunto do Programa de Mestrado e doutorado em Ciências Ambientais e Sustentabilidade na Amazônia, da UFAM - Universidade Federal do Amazonas.E-mail:v_pozzetti@hotmail.com.
\end{abstract}

\section{REBECA LUCAS CAMILO SUANO LOUREIRO} Mestranda em Direito Ambiental pela Universidade do Estado do Amazonas. Pósgraduada em Direito Público pela Universidade do Sul da Santa Catarina - UNISUL. Pós-graduanda em Direito Notarial e Registral pela Universidade Damásio. ManausAM. E-mail: rsuano@gmail.com.

\section{JOÃO FERNANDES CARNEIRO JÚNIOR} Mestrando em Direito Ambiental pela Universidade do Estado do Amazonas. Pósgraduado em Direito Constitucional pela Universidade de Anhanguera. Professor universitário e advogado. Manaus-AM. E-mail: juri.carneiro@gmail.com

\section{RESUMO}

O objetivo desta pesquisa foi o de tecer considerações sobre a possibilidade da extinção da obrigatoriedade da rotulagem de alimentos transgênicos, avaliando os 
Personalidade Acadêmica Homenageada:

Augustus B. Cochran III (Agnes Scott College)

princípios da função social da empresa, da precaução e da defesa do consumidor, principalmente quanto seu direito à informação. A metodologia utilizada nesta pesquisa foi a do método dedutivo e, quanto aos meios, a pesquisa foi bibliográfica, com o auxílio da doutrina e da legislação. Quanto aos fins, foi uma pesquisa qualitativa. Concluiu-se que existem vários discursos favoráveis à transgenia, principalmente por parte do setor agroindustrial e de entes governamentais que firmam parcerias e recebem recursos de empresas ligadas ao setor. Estas pesquisas concluem que as inovadoras técnicas empregas na produção de organismos geneticamente modificados (OGMs) são aptos a produzir mais comida, com qualidade, a um custo menor e com menor área de cultivo. As empresas envolvidas com os transgênicos alegam que estas inovações buscam um desenvolvimento socioeconômico e ambiental e, consequentemente, atendem o princípio da função social previsto na Constituição. Apesar disso, há expressiva resistência da sociedade contra os alimentos transgênicos, uma vez que esses argumentos carecem de comprovação científica unânime. Principalmente porque existem outras pesquisas, realizadas por instituições independentes que alertam sobre 0 surgimento de novas alergias e intolerâncias, em proporções de pandemia, e até câncer, associados ao consumo desses alimentos. Assim, diante de um impasse, o setor interessado, buscando a perda da obrigatoriedade da rotulagem dos alimentos transgênicos, passa a especular a existência de uma suposta ideologia contra transgênicos. Entretanto, mesmo sem se aprofundar no cerne da discussão sobre os efeitos positivos ou negativos da transgenia, pode-se perceber que tal exoneração não está em harmonia com o princípio da precaução; ao contrário, representa um retrocesso social, pois ofende também um direito fundamental, o da defesa do consumidor, sobretudo, o de ser informado e de poder exercer sua liberdade de escolha por produtos que não sejam geneticamente modificados. 
Personalidade Acadêmica Homenageada:

Augustus B. Cochran III (Agnes Scott College)

PALAVRAS-CHAVES: Consumidor; Função Social da Empresa; Princípio da Informação; Rotulagem; Transgênicos.

\section{ABSTRACT}

The objective of this research was to consider the possibility of abolishing the mandatory labeling of transgenic foods, evaluating the principles of the company's social function, precaution and consumer protection, especially regarding its right to information. The methodology used in this research was that of the deductive method and, in terms of means, the research was bibliographical, with the aid of doctrine and legislation. As for the ends, it was a qualitative research. It was concluded that there are several discourses favorable to transgenics, mainly by the agroindustrial sector and government entities that establish partnerships and receive funds from companies related to the sector. These researches conclude that the innovative techniques used in the production of genetically modified organisms (GMOs) are able to produce more food, with quality, at a lower cost and with less area of cultivation. The companies involved with transgenics claim that these innovations seek socioeconomic and environmental development and, consequently, they comply with the principle of the social function provided for in the Constitution. Despite this, there is significant resistance from society against transgenic foods, since these arguments lack more unanimous scientific evidence. Mainly because there are other studies carried out by independent institutions that warn of the emergence of new allergies and intolerances, in proportions of pandemic, and even cancer, associated with the consumption of these foods. Thus, faced with an undeniable impasse, the interested sector, seeking the loss of the obligatory labeling of transgenic foods, starts to speculate the existence of a supposed ideology against transgenics. However, even without going into the heart of the discussion of the positive or negative effects of transgenics, it can be seen that this exoneration conflicts head-on with the 
Personalidade Acadêmica Homenageada:

Augustus B. Cochran III (Agnes Scott College)

precautionary principle. In addition, it represents a social retrogression, as it also offends a fundamental right, that of consumer protection, above all, to be informed and to be able to exercise their freedom of choice for products that are not genetically modified.

KEYWORDS: Consumer; Social Role of the Company; Principle of Information; Labeling,; Transgenic.

\section{INTRODUÇÃO}

Nas últimas décadas, a agroindústria, em todo o mundo, tem experimentado inúmeras transformações, são várias inovações tecnológicas, novos equipamentos, automação, rastreabilidade da produção e até mesmo a alteração genética de seus produtos, os Organismos Geneticamente Modificados (OGMs), popularmente conhecidos como transgênicos.

Os organismos transgênicos são aqueles que foram desenvolvidos pela ciência, através de um processo de melhoramento, através da manipulação genética e com avançadas técnicas de engenharia genética. Esta técnica permite a transferência do gene de uma espécie para outra.

Atualmente, vários alimentos disponíveis nas prateleiras dos supermercados têm pelo menos um componente transgênico, seja a soja, milho ou alguma vitamina produzida de um organismo geneticamente modificado. A maçã ou o tomate disponível aos consumidores não são mais encontrados dessa forma na natureza, são o resultado de cruzamento e seleções, com mutagênese do DNA, radiação e dentre outras técnicas.

O setor agroindustrial tem divulgado pesquisas ressaltando a aptidão da transgenia para produzir mais comida, com qualidade, a um custo menor e com 
Personalidade Acadêmica Homenageada:

Augustus B. Cochran III (Agnes Scott College)

menor área de cultivo, aumentando a produção, reduzindo custos, disponibilizando, assim, mais comida, por um menor preço, sendo uma solução virtuosa para inúmeros gargalos de produção e, consequentemente, ajudando a combater a fome no mundo.

Entretanto, muitos destes estudos tem sido alvos de várias críticas. A principal delas é a falta de controle quanto às implicações do consumo destes produtos OGMs, principalmente pelos seres humanos. Algumas pesquisas mais hostis dão conta de sua relação com o aumento do número de casos de graves doenças, as quais vão desde riscos alergênicos até o câncer. Neste sentido, Ferment (2015, p. 307) esclarece que:

\begin{abstract}
Mais de 750 pesquisas cujos resultados são desprezados pelos órgãos reguladores da produção de organismos geneticamente modificados (OGMs). As pesquisas alertam que os casos de novas alergias e intolerâncias assumem proporção de pandemia, paralelamente à expansão das lavouras e dos alimentos geneticamente modificados, alertam também que o princípio ativo do glifosato, um agrotóxico muito utilizado para produção de OGMs para o controle de plantas daninhas, está associado a reações cancerígenas dentre outros.
\end{abstract}

Assim, tem-se no país uma inegável falta de unanimidade quanto às consequências do consumo de transgênicos, seus pontos positivos e negativos. Com posicionamentos contrários, o setor produtivo e parte da sociedade civil disputam espaços no cenário político nacional, na tomada de decisões relevantes que impactam significativamente a produção destes alimentos e o consumo da população.

Neste cenário de incertezas, surge o Projeto de Lei da Câmara dos Deputados $n^{\circ} 34 / 2015$ (PLC 34/2015), que tem o objetivo de viabilizar a remoção do triângulo amarelo com a letra "T", de uso obrigatório nos rótulos de alimentos transgênicos desde 2005.

Nasce daí a necessidade de se refletir sobre o que determina a lei e a própria Constituição, identificando, principalmente, os princípios que guardam 


\section{Personalidade Acadêmica Homenageada:}

\section{Augustus B. Cochran III (Agnes Scott College)}

relação com o tema. Desta forma, o questionamento trazido nesta pesquisa é: "de que forma a legislação e os princípios de Direito disciplinam a possibilidade de retirada da obrigatoriedade da rotulagem de alimentos transgênicos, sem trazer prejuízos ao meio ambiente e à saúde do consumidor?".

Essa pesquisa se justifica tendo em vista que há sérios indícios de que o PL no 34/2015, fere o constitucional direito de informação e o princípio do não retrocesso ambiental, trazendo consequências desastrosas para o desenvolvimento sustentável, nas esferas econômica, social e ambiental.

Este estudo é imprescindível para o amadurecimento e o debate do PL no 34/2015 que, atualmente está em fase deliberativa, no Senado Federal. É importante destacar que não sequer fazer cessar as pesquisas, mas sim, que elas avancem com o mínimo de segurança possível ao consumidor e ao meio ambiente, sem impor riscos à saúde coletiva e à conservação do meio ambiente, direito fundamental previsto no artigo 225 da Constituição.

A metodologia utilizada nessa pesquisa é a do método dedutivo; quanto aos meios a pesquisa será a bibliográfica; quanto aos fins a pesquisa será qualitativa.

\section{OBJETIVOS}

O objetivo geral desta pesquisa é o de tecer considerações sobre a possibilidade da extinção da obrigatoriedade da rotulagem de alimentos transgênicos, avaliando quais os princípios mais relevantes, tendo-os como mandamentos que buscam sua finalidade em consonância com o contexto analisado.

Assim, especificamente, busca-se investigar qual a relação entre a possibilidade de extinção da rotulagem de alimentos transgênicos e o princípio da 
Personalidade Acadêmica Homenageada:

Augustus B. Cochran III (Agnes Scott College)

função social da propriedade, o princípio ambiental da precaução e o princípio da informação, como direito do consumidor.

\section{METODOLOGIA}

A metodologia utilizada nesta pesquisa foi a do método dedutivo; quanto aos meios, foi desenvolvida através do método dedutivo, descritivo utilizando da pesquisa bibliográfica com consulta à legislação, periódicos e jurisprudência; quanto aos fins a pesquisa é qualitativa, onde se produz um resultado que trará reflexões e conclusões de qualidade.

\section{DESENVOLVIMENTO}

Segundo Pozzetti e Rodrigues (2018, p. 2) "no Brasil, os alimentos transgênicos começaram a ganhar mercado nos anos 90, após a edição da 1a Lei de Biossegurança, sendo suscitados posicionamentos favoráveis e contra a edição da Lei".

O PLC no 34/2015 visa alterar a Lei de Biossegurança ${ }^{1}$ modificando as regras para identificação e rotulagem de produtos transgênicos. Segundo este Projeto de Lei, o alimento geneticamente modificado que contiver a presença de

\footnotetext{
${ }_{1}^{1}$ A Lei de Biossegurança, Lei n ${ }^{\circ} 11.105 / 05$, regulamenta os incisos II, IV e V do $\S 10$ do art. 225 da Constituição Federal, estabelece normas de segurança e mecanismos de fiscalização sobre a construção, o cultivo, a produção, a manipulação, o transporte, a transferência, a importação, a exportação, o armazenamento, a pesquisa, a comercialização, o consumo, a liberação no meio ambiente e o descarte de organismos geneticamente modificados - OGM e seus derivados, tendo como diretrizes o estímulo ao avanço científico na área de biossegurança e biotecnologia, a proteção à vida e à saúde humana, animal e vegetal, e a observância do princípio da precaução para a proteção do meio ambiente.
} 


\section{Personalidade Acadêmica Homenageada:}

Augustus B. Cochran III (Agnes Scott College)

mais de $1 \%$ de transgenia, deve ser identificado como tal, devendo seu rótulo conter o símbolo de transgênico.

Ou seja, aprovado o PL № 34/2015, haverá a retirada do símbolo "T" (grafado em cor preta, dentro de um triangulo amarelo) que hoje é obrigatório constar na embalagem de todo alimento transgênico, utilizado para a identificação dos alimentos transgênicos, como direito sagrado de informação e escolha, por parte do consumidor. Assim, todo alimento, hoje, que contém mais de $1 \%$ de transgenia, na análise laboratorial final, deve conter em seu rótulo, obrigatoriamente, a expressão "contém transgênico" no rótulo, seguido do "T".

Atualmente, a análise da presença de transgenia no produto é feita com testes em suas matérias-primas. Entretanto, muitos produtos disponíveis ao consumidor são ultra processados e, em função da alteração química que esse produto sofre, seu material genético pode ser alterado, ou seja, ser mascarado.

Quando a análise laboratorial se dá apenas no estágio final da produção, há uma maior dificuldade de detecção do elemento transgênico, comprometendo sua rastreabilidade, impedindo, inclusive, o monitoramento de seus efeitos pelo consumo humano.

Neste sentido destacam Pozzetti e Rodrigues (2018, p.9):

Embora o Projeto de Lei no 34/15, em tramitação, tenha por objeto alterar apenas 0 art. 40 da Lei de Biossegurança, se aprovado, acarretará modificações significativas no que tange o uso, a produção e a venda dos produtos transgênicos no Brasil. Isso porque a obrigatoriedade de informar o consumidor sobre a existência de produtos transgênicos será restrita a concentração de transgênicos superior a $1 \%$ apenas no produto final, detectada em análise específica. Para alimentos ou ingredientes alimentares que obtivessem resultado negativo na análise específica seria facultado o uso da expressão "livre de transgênicos".

E continuam Pozzetti e Rodrigues (2018, p. 9): 


\section{Personalidade Acadêmica Homenageada: \\ Augustus B. Cochran III (Agnes Scott College)}

Dentre outras consequências, a proposta do Projeto de Lei, reduziria a facilidade de identificação do produto transgênico pelo consumidor, vez que a informação sobre a transgenia somente estaria presente nas pequenas letras do rótulo das embalagens, havendo ainda a possibilidade de comercialização de produtos com matéria-prima de origem transgênica sem que a informação fosse repassada ao consumidor.

Assim, tem-se que o PLC $n^{0}$ 34/2015, se aprovado, pode significar, na prática, uma vedação legal à identificação dos alimentos transgênicos, algo que suscita a análise dos princípios que disciplinam a matéria.

\section{PRINCÍPIOS}

Os princípios são mandamentos que precedem às leis. São os valores de honestidade e diretrizes que uma determinada sociedade possui, em relação aos comportamentos de cada indivíduo que compõem aquele grupo social.

Segundo Pozzetti e Campos (2017, p.255):

Os princípios são a base do ordenamento jurídico, de onde promanam as regras de uma determinada sociedade. Tudo aquilo que determinada sociedade entende como justo, como honesto, como norte para a paz e a vida em grupo, é denominado de princípios. Dessa forma, a norma jurídica, ao ser posta a disposição de todos os jurisdicionados, deverá atender as regras ou aos anseios dos Princípios; caso contrário, está fadada a ser revogada.

Já para Alexy (2008, p. 90):

Princípios são normas que ordenam que algo seja realizado na maior medida possível dentro das possibilidades jurídicas e fáticas existentes. Princípios são, por conseguinte, mandamentos de otimização, que são caracterizados por poderem ser satisfeitos em graus variados e pelo fato de que a medida devida de sua satisfação não depende somente das possibilidades fáticas, mas também das possibilidades jurídicas. 
Personalidade Acadêmica Homenageada:

Augustus B. Cochran III (Agnes Scott College)

Diretamente relacionados com a aprovação da PLC no 34/2015, destacamse, como cerne desta pesquisa, três mandamentos de otimização mais relevantes, são eles: o princípio da função social da empresa, o princípio da precaução e o princípio do direito à informação.

Desafiando uma análise mais detalhada, até para que se possa reconhecer até que medida a aplicação de um princípio pode ser suavizado por necessidade de observância de outro mais prevalente, passa-se a abordagem mais individualizada, de acordo com o contexto analisado.

\title{
PRINCÍPIO DA FUNÇÃO SOCIAL DA EMPRESA
}

A propriedade, há muito, deixou de ser considerada um direito absoluto. Sendo assegurada pela Constituição, ela se legitima, tornando-se válida e autêntica, quando seu uso atende a função social. Toda pessoa, seja física ou jurídica, que possui uma propriedade, principalmente, um bem de produção, isto é, uma indústria ou comércio, deve atuar observando o dever de proporcionar o bem-estar de toda a coletividade, como preceitua Justen Filho (1998, p. 130):

\begin{abstract}
A atividade empresarial pode ser considerada como instrumento de realização dos valores pessoais e egoísticos do empresário. Mas não se legitimou a empresa, constitucionalmente, apenas sob esse aspecto. O que dá sustentação constitucional ao instituto da empresa é sua vocação para realização da dignidade de cada pessoa humana. [...] Nenhum tipo de exploração empresarial será legítima quando conduzir ao sacrifício dos interesses grupais e coletivos. A realização do lucro somente pode ser validada quando conduzir ao bem-estar grupal.
\end{abstract}

Tida como um dos fundamentos da República Federativa do Brasil, previstos no art. $3^{\circ}$, que estabelece os objetivos fundamentais do Estado brasileiro e no artigo 170, que institui como fundamentos da ordem econômica a valorização do trabalho 
Personalidade Acadêmica Homenageada:

Augustus B. Cochran III (Agnes Scott College)

humano e a livre iniciativa, a função social da empresa garante a todos(trabalhadores e sociedade) uma vida digna, de acordo com a justiça social.

As empresas do setor agroindustrial, como qualquer outra empresa atuante no mercado nacional, devem observar não apenas os deveres de boa-fé contratual e da livre iniciativa, mas deveres para com os consumidores e o meio ambiente, a fim de promover um pleno desenvolvimento sustentável.

Portanto, todo aprimoramento tecnológico que possa maximizar o progresso econômico, social e ambiental, não deve servir de diferencial com vistas somente ao fim de lucro, mas também para buscar a efetivação dessa função social, como bem ensina Maria Helena Diniz:

Pela teoria da função social da empresa, o empresário e a sociedade empresária deverão ter o poder-dever de, no desenvolvimento de sua atividade, agir a serviço da coletividade. A propriedade empresarial deverá atender à função social, exigida pela Carta Magna (arts. 5o , XXII , 182, §º , e 186); por isso o empresário exercerá sua atividade econômica organizada de produção e circulação de bens e serviços no mercado de consumo, de forma a prevalecer a livre concorrência sem que haja abuso de posição mercadológica dominante, procurando proporcionar meios para a efetiva defesa dos interesses do consumidor e a redução de desigualdades sociais [...] É preciso compatibilizar essa sua função social, visando o bem-comum, o bem-estar e a justiça social, com a finalidade de produção de lucros. (DINIZ, 2018, p. 394-395)

Diante do objetivo comum de buscar o desenvolvimento sustentável, parece se sobressair o direito da sociedade de se beneficiar dos aprimoramentos tecnológicos alcançados pela transgenia. É em nome da função social, que assegura o direito da sociedade às benesses atribuídas as modificações genéticas na produção de alimentos, que o setor agroindustrial busca desacreditar o resultado de pesquisas contrárias aos seus interesses.

A agroindústria tem se utilizado do discurso de que tais pesquisas são a reprodução de uma ideologia contrária aos OGMs, como se pode identificar no posicionamento de José Robson Bezerra Sereno, Chefe-Geral da Empresa 
Personalidade Acadêmica Homenageada:

Augustus B. Cochran III (Agnes Scott College)

Brasileira de Pesquisa Agropecuária $\left(E \mathrm{mbrapa}^{2}\right)$, vinculada ao Ministério da Agricultura:

Atualmente, a mídia está sendo bombardeada apor inúmeras reportagens sobre a biotecnologia e os produtos transgênicos, muitas vezes sem o devido embasamento técnico-científico. As informações repassadas para a sociedade, muitas vezes são deturpadas por ideologias, medo, sensacionalismo e pela própria desinformação. (FALEIRO, 2009, p.13)

Percebe-se que, em nome da função social da empresa, o setor interessado, incapaz de demonstrar cientificamente que a resistência aos transgênicos é infundada, reproduz o argumento de que existe uma ideologia radical com o fim de retirar a obrigatoriedade da rotulagem, colocando em risco a saúde desta própria sociedade. Neste sentido, cabe o que pontua Silveira (2015, p.321-322):

A função social da empresa exige desta uma atividade voltada para os fins sociais e ambientais, e para os objetivos relacionados ao interesse coletivo. Não implica somente no cumprimento efetivo das obrigações legais e na observância dos direitos sociais trabalhistas e tributários, mas também no compromisso com a preservação ambiental, relacionamento ético com fornecedores e consumidores, bem como o cuidado com o impacto de sua atuação na comunidade onde está inserida. Ou seja, além da função social, há também a função solidária.

Constata-se, assim, que a função social da empresa, mesmo visando cumprir seu dever de partilhar os benefícios dos aprimoramentos da biotecnologia, não pode permitir, pelos próprios valores nela inseridos, como o bem-comum, o bem-estar, a justiça social, os interesses dos consumidores e a própria dignidade humana, que os interesses de produção e de lucro do setor agroindustrial possam ser colocados acima da incolumidade pública, o que consistiria em uma contradição.

${ }^{2}$ Criada em abril de 1973, a Empresa Brasileira de Pesquisa Agropecuária (Embrapa), vinculada ao Ministério da Agricultura, Pecuária e Abastecimento, tem como missão viabilizar soluções de pesquisa, desenvolvimento e inovação para a sustentabilidade da agricultura, em benefício da sociedade brasileira. 
Personalidade Acadêmica Homenageada:

Augustus B. Cochran III (Agnes Scott College)

Com o fim de aclarar o tema em relação às incertezas científicas que envolvem os malefícios do consumo de alimentos geneticamente modificados, merece destaque o princípio da precaução, concebido do direito ambiental.

\section{PRINCÍPIO DA PRECAUÇÃO}

Este princípio foi consagrado na Conferência das Nações Unidas sobre o Meio Ambiente e o Desenvolvimento, também conhecida como Eco-92, a qual reuniu chefes de estado na cidade do Rio de Janeiro, em 1992. Sendo intitulado como Princípio 15, o Princípio da Precaução estabelece que:

Para proteger o meio ambiente, medidas de precaução devem ser largamente aplicadas pelos Estados, segundo suas capacidades. Em caso de risco de danos graves e irreversíveis, a ausência de certeza científica absoluta não deve servir de pretexto para procrastinar a adoção de medidas visando prevenir a degradação do meio ambiente.

Segundo o princípio da precaução, se determinada tecnologia apresenta uma incerteza científica, ameaçando o meio ambiente pelo risco de ocorrência de graves ou mesmo irreversíveis danos, deve-se adiar seu uso econômico até que se tenha uma compreensão científica mais precisa. Neste sentido, instrui Sarlet (2017, p. 215-216):

A ausência de um conhecimento científico adequado para assimilar a complexidade dos fenômenos ecológicos e os efeitos negativos de determinadas técnicas e substâncias empregadas pelo ser humano podem levar, muitas vezes, a situações irreversíveis do ponto de vista ambiental, como, por exemplo, a extinção de espécies da fauna e da flora, além da degradação de ecossistemas inteiros. [...] A questão posta pelo princípio da precaução [...] é justamente identificar os riscos e, ao invés de aguardar pelo pior, passar a intervenção no sentido de adotar medidas para que as consequências negativas não ocorram. 
Personalidade Acadêmica Homenageada: Augustus B. Cochran III (Agnes Scott College)

Não se pode, em nome de um procedimento técnico inovador e desconhecido, por gerar expectativas de ganhos de produção, correr o risco de transferir os custos de suas externalidades à possíveis vítimas, como já ocorreu em um passado recente, principalmente quanto ao tabagismo e o uso do medicamento Talidomida. Neste sentido, Pozzetti (2014, p. 106/107) esclarece com pertinência:

Às vezes, se esperarmos por comprovações, será tarde demais. Os padrões científicos para a demonstração de causa e efeito são muito elevados. Por exemplo: já havia a forte suspeita de que fumar provocava câncer do pulmão muito antes desta associação ter sido estabelecida de forma conclusiva, isto é, ter atendido aos padrões científicos de causa e efeito. Àquela altura, muitos fumantes já haviam morrido de câncer do pulmão. $\mathrm{O}$ planeta já experimentou algo semelhante, quando os laboratórios produziram a Talidomida, para evitar os enjoos que acometiam as mulheres grávidas. Os resultados foram desastrosos: crianças má formadas e/ou defeituosas, etc.

E continua Pozzetti (2016, p.167):

Este princípio é utilizado quando, na atividade que se quer realizar, há incerteza científica, de dano ambiental. Estabelece a vedação de intervenções no meio ambiente, salvo se houver a certeza que as alterações não causarão reações adversas, já que nem sempre a ciência pode oferecer à sociedade respostas conclusivas sobre a inocuidade de determinados procedimentos.

Para aclarar sobre os riscos da transgenia, pode-se pontuar que, se analisado sob um aspecto antropocêntrico³ ${ }^{3}$, há estudos que investigam males que vão desde a incidência de alergias alimentares, causadas por hipersensibilidade a um gene inserido de uma espécie diferente, até má formação fetal, envelhecimento precoce, Alzheimer, autismo e câncer.

\footnotetext{
${ }^{3}$ Segundo Fiorillo (2013, p. 481), anteriormente havia uma visão predominantemente fechada aos interesses humanos, no que aqui se denomina antropocentrismo estrito. Esse quadro modifica-se com a constatação de que o enfoque nas necessidades humanas não representa uma garantia de futuro tranquilo em termos ambientais. Nesse sentido iniciam-se, no final da década de 1980 e início de 1990, propostas teóricas que privilegiam um enfoque biocêntrico para as discussões ambientais. Tais concepções sustentam o reconhecimento de outros sujeitos de direito [formas de vida não humanas, como animais e plantas, por exemplo] no núcleo central do ordenamento jurídico.
} 


\section{Personalidade Acadêmica Homenageada:}

Augustus B. Cochran III (Agnes Scott College)

Caso seja analisado sob o aspecto biocêntrico, há o perigo de extinção de espécies vegetais, dizimando culturas inteiras e acabando com a diversidade biológica, além da contaminação da água pelo uso indiscriminado de glifosato.

Estas pesquisas assinalam motivos relevantes para nortear, no mínimo, a adoção de uma postura de cautela ante a liberação de produção de OGMs em larga escala, quanto mais a quase que absoluta ausência de rastreabilidade pela desobrigação legal da rotulagem destes alimentos transgênicos. Neste sentido, esclarece Maria Helena Diniz:

Deverá haver prudência por parte da sociedade empresária relativamente ao uso da biotecnologia, na alteração de composição genética da flora e da fauna, criando organismos geneticamente modificados, em busca de maior produtividade na agropecuária, na indústria de alimentos e remédios etc. Foi a grande atuação empresarial, devida à globalização, que fez com que os países não mais tornassem impunes os atos poluidores de pessoas jurídicas, admitindo sua responsabilidade penal pelos danos que causarem ao meio ambiente. (DINIZ, 2018, p. 403).

Assim, pode-se constatar que, como o uso da biotecnologia ainda representa um risco, seja para o meio ambiente natural, seja para o consumo humano, tem-se que evitar seu uso generalizado até que exista um mínimo de segurança científica, este é o dever de cautela imposto pelo Princípio da Precaução.

Neste sentido, se mostra temerária a desobrigação de rotulagem dos alimentos transgênicos, pois apesar de já haver uma relativa inobservância deste princípio, visto que a produção e o consumo de transgênicos é permitido no Brasil. Sua não identificação corresponderia a completa transferência das externalidades desta atividade ao consumidor, vez que inviabilizaria também sua rastreabilidade, impedido, principalmente, a responsabilização das empresas por eventuais danos à saúde dos consumidores.

Analisando o tema sob o aspecto do consumidor, especialmente no que diz respeito microssistema legal de proteção instituído pela Constituição, indispensável a análise do princípio da informação. 
Personalidade Acadêmica Homenageada:

Augustus B. Cochran III (Agnes Scott College)

\section{PRINCÍPIO DA INFORMAÇÃO DO CONSUMIDOR}

A Constituição estabelece em seu art. $5^{\circ}$, inciso XIV, que fica assegurado a todos o direito à informação. De uma maneira geral, o texto constitucional impõe a disponibilização da informação por quem a detenha, principalmente no caso dos entes e órgãos públicos. Portanto, se a Constituição garante o direito de qualquer pessoa ser informada, isso implica no surgimento de um dever para outra, como bem explica Nunes (2012, p. 98):

Sabe-se que o exercício de um direito subjetivo significa a possibilidade da exigência de alguém. Isto é, a prerrogativa de um corresponde à obrigação de outro. Assim, quando a Constituição garante a todos o acesso à informação, tem-se de entender que essa informação deve estar com alguém que terá a obrigação de fornecê-la.

Já para Pozzetti (2016, p. 169), "a informação está ligada à Educação Ambiental, que é o "mote' da eficácia de aplicabilidade desse Princípio".

Nasce da própria Constituição a obrigação de informar a que todo fornecedor está vinculado. Isto porque, ao se analisar melhor tem-se a disposição sobre os deveres da empresa, onde há uma especial atenção à defesa do consumidor, como se pode observar pelo teor do art. 170, destacado a seguir:

Constituição. Art. 170. A ordem econômica, fundada na valorização do trabalho humano e na livre iniciativa, tem por fim assegurar a todos existência digna, conforme os ditames da justiça social, observados os seguintes princípios:[...] $\vee$ - defesa do consumidor;

Esta defesa do consumidor foi prevista também foi art. 5oㅡ, inciso XXXII, inserido no rol de direitos fundamentais, onde a constituição estatui que ela será promovida na forma da lei, isto é, nos termos da Lei $n^{\circ} 8.078 / 90$, o Código de Defesa do Consumidor (CDC). 
Personalidade Acadêmica Homenageada:

Augustus B. Cochran III (Agnes Scott College)

Não é à toa que a Constituição, quando trata da relação de consumo, faz menção ao termo "defesa do consumidor". Está claro que o consumidor não possui, na maioria das vezes, o conhecimento técnico e a capacidade econômica para estabelecer uma relação jurídica justa com o fornecedor. A empresa tem capital e expertise, podendo facilmente subjugar o consumidor.

Devido esta disparidade na relação jurídica, tem-se a legislação consumerista, para coibir os excessos das empresas e promover a defesa do consumidor, uma vez que ele é, de modo presumido, vulnerável técnica, econômica e culturalmente. Neste sentido, o CDC é considerado matéria de ordem pública, de observância obrigatória, que retira seu fundamento de validade diretamente da Constituição, devendo, inclusive, prevalecer sobre as demais leis, como bem elucida Mirage (2016, p. 68):

A nosso ver, nessa acepção é que devem ser vislumbradas as características indicadas pelo Código de Defesa do Consumidor em seu artigo $1^{\circ}$. A determinação da lei como de ordem pública, revela um status diferenciado à norma que, uma ordem pública de proteção em razão da vulnerabilidade reconhecida ao consumidor que, embora não a tome hierarquicamente superior às demais, Ihe outorga um caráter preferencial. De outra parte, na medida em que realiza o conteúdo de um direito fundamental, de matriz constitucional, retira da esfera de autonomia privada das partes a possibilidade de derrogá-la (norma imperativa).

Em se tratando do direito de informação do consumidor é inegável que, apesar da Constituição não prever expressamente a obrigação do fornecedor, o CDC a estabelece com propriedade, inclusive impondo sanções de natureza criminal, como se verá adiante.

O direito de ser informado nasce, sempre, do dever que alguém tem de informar. Basicamente, o texto magno estabelece o dever de informar que têm os órgãos públicos. No que tange ao dever de informar das pessoas em geral e das pessoas jurídicas com natureza jurídica privada, é o Código de Defesa do Consumidor que estabelece tal obrigatoriedade ao fornecedor. Tendo em vista que a Lei n. 8.078/90 nasce, como vimos, das determinações constitucionais que obrigam a que seja feita a defesa do 


\section{Personalidade Acadêmica Homenageada:}

Augustus B. Cochran III (Agnes Scott College)

consumidor, implantada em meio a uma série de princípios, todos interpretados e aplicáveis de forma harmônica, não resta dúvida de que o dever de informar só podia ser imposto ao fornecedor. (NUNES, 2012, p. 99)

$\mathrm{O}$ art. $6^{\circ}$, inciso III, do CDC, estabelece como direito básico do consumidor: "a informação adequada e clara sobre os diferentes produtos e serviços, com especificação correta de quantidade, características, composição, qualidade, tributos incidentes e preço, bem como sobre os riscos que apresentem".

Um dos pontos de grande polêmica sobre o tema é a resistência de entidades estatais que vêm sendo financiadas por grandes empresas de biotecnologia, a exemplo da parceria existente entre a Monsanto e a Embrapa 4 . Fato que coloca sob suspeita os resultados de suas pesquisas, viso que parte da mídia as acusam de esconder informações relevantes sobre a qualidade e os riscos dos produtos transgênicos.

Este flagrante desrespeito ao CDC é considerado crime, previsto no art. 69: "Deixar de organizar dados fáticos, técnicos e científicos que dão base à publicidade: Pena Detenção de um a seis meses ou multa".

A informação, principalmente para o consumidor, é um direito fundamental, básico e indispensável. Sem a informação adequada ele não tem liberdade de escolha, restando impossibilitado de exercer o consumo consciente. Por esta razão o CDC estabelece no art. 31, como a empresa deve informar o consumidor acerca de seu produto:

Lei 8.078/90. Art. 31. A oferta e apresentação de produtos ou serviços devem assegurar informações corretas, claras, precisas, ostensivas e em língua portuguesa sobre suas características, qualidades, quantidade,

\footnotetext{
${ }^{4}$ Oito projetos voltados para o desenvolvimento sustentável da agricultura brasileira receberem, ao todo, em 2012, $R \$ 3,8$ milhões do Fundo Embrapa-Monsanto. O valor é parte do arrecadado em direitos de propriedade intelectual, a título de royalties, com a venda de variedades de soja da Embrapa com tecnologia Roundup Ready na safra 2010/2011. Ademais, a Monsanto já repassou ao Fundo de Pesquisa, de 2006 a 2012, mais de $R \$ 29$ milhões que beneficiaram dezenas de projetos, em sua maioria em biotecnologia, de diversas unidades da Embrapa. (EMBRAPA, 2012)
} 


\section{Personalidade Acadêmica Homenageada: Augustus B. Cochran III (Agnes Scott College)}

composição, preço, garantia, prazos de validade e origem, entre outros dados, bem como sobre os riscos que apresentam à saúde e segurança dos consumidores.

Extinguir a obrigatoriedade de rotulagem dos produtos transgênicos implicaria na supressão de informação imprescindível e consistiria em comunicação de informação falsa, por omissão. Seria uma publicidade enganosa, nos termos do art. 37, do CDC:

Lei 8.078/90. Art. 37. É proibida toda publicidade enganosa ou abusiva. § $1^{\circ}$ É enganosa qualquer modalidade de informação ou comunicação de caráter publicitário, inteira ou parcialmente falsa, ou, por qualquer outro modo, mesmo por omissão, capaz de induzir em erro o consumidor a respeito da natureza, características, qualidade, quantidade, propriedades, origem, preço e quaisquer outros dados sobre produtos e serviços. [...] $§ 3^{\circ}$ Para os efeitos deste código, a publicidade é enganosa por omissão quando deixar de informar sobre dado essencial do produto ou serviço.

Ademais, o CDC define como crime fazer afirmação falsa ou enganosa, ou omitir informação relevante, assim como fazer ou promover publicidade que sabe ou deveria saber ser enganosa ou abusiva, nos termos dos artigos 66 e 68:

Lei 8.078/90. Art. 66. Fazer afirmação falsa ou enganosa, ou omitir informação relevante sobre a natureza, característica, qualidade, quantidade, segurança, desempenho, durabilidade, preço ou garantia de produtos ou serviços: Pena - Detenção de três meses a um ano e multa. [...] Lei 8.078/90. Art. 68. Fazer ou promover publicidade que sabe ou deveria saber ser capaz de induzir o consumidor a se comportar de forma prejudicial ou perigosa a sua saúde ou segurança: Pena - Detenção de seis meses a dois anos e multa.

Por fim, constata-se que caso o PLC 34/2015 seja aprovado, haverá uma colisão frontal com todo o microssistema de defesa do consumidor. Sistema este que retira seu fundamento de validade diretamente da Constituição, possuindo status de direito fundamental. Neste sentido, a desobrigação legal da rotulagem dos alimentos transgênicos corresponderia a uma inobservância constitucional que 
Personalidade Acadêmica Homenageada:

Augustus B. Cochran III (Agnes Scott College)

desafiará um provável controle de constitucionalidade ante o Supremo Tribunal Federal.

\section{CONSIDERAÇÕES FINAIS}

Em meio a grande controvérsia dos estudos sobre os possíveis riscos à saúde humana e ao meio ambiente, advindos da produção de alimentos geneticamente modificados, destaca-se, no cenário político nacional, o Projeto de Lei da Câmara $n^{\circ} 34 / 2015$, que tem o fim de retirar a obrigatoriedade de rotulagem de alimentos transgênicos, flexibilizando a lei de Biossegurança.

A problemática que motivou essa pesquisa foi a de se verificar de que forma o PL № 34/2015 poderia, se aprovado, garantir a saúde do consumidor e garantir a sua liberdade de escolha livre e consciente, como estabelece o Código de defesa do Consumidor.

Os objetivos da pesquisa foram atingidos na medida em que se analisou a legislação vigente e, especificamente, os princípios mais conexos que disciplinam o tema, para que se pudesse esclarecer melhor as consequências jurídicas de sua aprovação; assim, os objetivos foram cumpridos à medida que foram analisados tanto a Constituição como o princípio da função social da empresa, o princípio da precaução, o princípio da informação e o microssistema de defesa do consumidor.

Como resultado desta pesquisa constatou-se que o setor agroindustrial e as empresas de biotecnologia querem se valer do argumento da existência de uma suposta ideologia contrária aos transgênicos, a qual impediria o pleno usufruto, por toda a sociedade, das benesses advindas da transgenia. Este discurso de frustração da função social da empresa tem o objetivo de legitimar o fim de rotulagem dos alimentos transgênicos. Entretanto, é esta mesma função social que, pelos próprios valores nela inseridos, a impede de produzir alimentos transgênicos 
Personalidade Acadêmica Homenageada:

Augustus B. Cochran III (Agnes Scott College)

inadvertidamente e em larga escala, vez que a incolumidade pública está acima dos possíveis ganhos.

Constatou-se também que o uso da biotecnologia ainda representa um risco, seja para o meio ambiente natural, seja para o consumo humano. O que implica a necessidade de se evitar seu uso generalizado até que exista um mínimo de segurança científica, sendo este o dever de cautela imposto pelo princípio da precaução. Portanto, uma vez eliminada a obrigatoriedade de rotulagem de transgênicos, é possível que ocorra a transferência das externalidades exclusivamente ao consumidor, vez que a rastreabilidade estaria comprometida, impedido, desse modo, a responsabilização das empresas por eventuais danos à saúde dos consumidores.

Ademais, caso o PLC no 34/2015 seja aprovado, haveria um verdadeiro retrocesso social, haja vista representar uma verdadeira colisão com todo o microssistema de defesa do consumidor, o qual possui status de direito fundamental.

Neste sentido, tal comando legal equivaleria a um desrespeito à Constituição, algo que suscitará, possivelmente, o controle repressivo da corte constitucional brasileira.

\section{REFERÊNCIAS}

ALEXY, Robert. Teoria dos direitos fundamentais. São Paulo: Malheiros, 2008.

BRASIL, Constituição da República Federativa do. Congresso Nacional, Brasília, 1988.

. Lei Federal no 8.078/90. Congresso Nacional, Brasília, 1990.

. Lei Federal no 11.105/05. Congresso Nacional, Brasília, 2005.

2015.

. Projeto de Lei da Câmara no 34/2015. Câmara dos Deputados, Brasília, 
Personalidade Acadêmica Homenageada:

Augustus B. Cochran III (Agnes Scott College)

DINIZ, Maria Helena. Importância da função social da empresa. Revista Jurídica, v.2, n.51, p.387-412, abr./jun. 2018.

EMPRESA BRASILEIRA DE PESQUISA AGROPECUÁRIA. Notícias. Monsanto repassa R\$ 3,8 milhões a pesquisas. Embrapa, Brasília, 05 março 2012. Disponível em: <https://www.embrapa.br/busca-de-noticias//noticia/1462378/monsanto-repassa-r-38-milhoes-a-pesquisas->. Acesso em: 29 maio 2019.

FALEIRO, F. G.; ANDRADE, S. R. M. Biotecnologia, transgênicos e biossegurança. Planaltina: Embrapa Cerrados, 2009.

FERMENT, Gilles et al. Lavouras transgênicas - riscos e incertezas: mais de 750 estudos desprezados pelos órgãos reguladores de OGMs. Brasília: Ministério do Desenvolvimento Agrário, 2015.

FIORILLO, Celso Antonio Pacheco. Curso de direito ambiental brasileiro. 14. Ed. São Paulo: Saraiva, 2013.

JUSTEN FILHO, Marçal. Empresa, ordem econômica e constituição. Revista de Direito Administrativo, v.212, p.109-133, abr./jun. 1998.

MIRAGEM, Bruno. Curso de direito do consumidor. 6 Ed. São Paulo: Editora Revista dos Tribunais, 2016.

NUNES, Luis Antonio Rizzatto. Curso de direito do consumidor. 7 Ed. São Paulo: Saraiva, 2012.

POZZETTI, Valmir César. Alimentos transgênicos e o direito do consumidor à informação. Revista Jurídica, v.3, n.36, p.313-327, jul./set. 2014.

. Direito Empresarial e a Natureza Jurídica do meio ambiente do trabalho Revista jurídica Unicuritiba; vol. 02, $\mathrm{n}^{\circ}$. 43, Curitiba, 2016. pp. 159-184. DOI: 10.6084/m9.figshare.3364015.

e CAMPOS, Jalil Fraxe. ICMS Ecológico: um desafio à sustentabilidade econômico ambiental no Amazonas. Revista Juridica Unicuritiba. Curitiba/PR. vol. 02, n. 47, Curitiba, 2017. pp. 251-276.

e RODRIGUES, Cristiane Barbosa. Alimentos Transgênicos e o Princípio da dignidade da pessoa humana. Revista Jurídica (FURB) ISSN 1982-4858 v. 22, №. 48, maio/ago. 2018. 
Personalidade Acadêmica Homenageada:

Augustus B. Cochran III (Agnes Scott College)

SARLET, Ingo Wolfgang. Princípios do direito ambiental. 2 Ed. São Paulo: Saraiva, 2017.

SILVEIRA, V. O.; SANCHES, S. H. F. N. Direitos humanos, empresa e desenvolvimento Sustentável. Revista Jurídica, v.1, n.38, p.313-327, jan./mar. 2015. 